\title{
Water quality assessment of Chenab river and its tributaries in Jammu Kashmir (India) based on WQI
}

\author{
G. K. Khadse ${ }^{1}$ - P. M. Patni ${ }^{1}$ - P. K. Labhasetwar ${ }^{1}$
}

Received: 25 June 2015/Accepted: 1 March 2016/Published online: 15 March 2016

(C) Springer International Publishing Switzerland 2016

\begin{abstract}
An assessment of the water quality has been carried out to explore the water quality index (WQI) of Chenab river and its tributaries in Jammu Kashmir (India). Fourteen water samples from Chenab river and its tributaries at various locations were collected and analyzed for physico-chemical and bacteriological parameters. Nine parameters i.e. BOD, DO, fecal coliforms, nitrate, $\mathrm{pH}$, temperature change, TDS, total phosphate and turbidity were considered for calculating the WQI based on National Sanitation Foundation (NSF) information system. The WQI showed good water quality, except Bichleri stream water indicating that water of Chenab river and its tributaries are least polluted and is suitable for drinking after conventional treatment. The WQI rating of Bichleri stream water is medium as it carries wastewater and may not be useful for domestic use without treatment.
\end{abstract}

Keywords Water quality index $\cdot$ Physico-chemical parameters $\cdot$ Bacteriological parameters

\section{Introduction}

An integral part of any environmental monitoring program is the reporting of results to both managers and the general public. This poses a particular problem in the case of water quality monitoring because of the complexity associated with analyzing a large number of measured variables. Water quality index (WQI) provides a convenient means of

G. K. Khadse

gk_khadse@neeri.res.in

1 CSIR-National Environmental Engineering Research Institute, Nagpur, India summarizing complex water quality data and facilitating its communication to a general audience (Kannan 1991; Sinha and Shrivastava 1994; Pradhan et al. 2001; Neary and Wright 2001). WQI was first formulated by Horton (1965) and later used by several workers for water quality assessment. It is one of the aggregate indices that has been accepted as a rating that reflects the composite influence on the overall quality of numbers of precise water quality characteristics (Tiwari and Mishra 1985). WQI is a dimensionless number with values ranking between 0 and 100 , where higher index value represents a good water quality (Cude 2001; Pandey and Sundaram 2002). Much of the work has been done on the water quality indices of several rivers of India and abroad by various workers viz., Bhatt and Pathak (1992), Kumar and Shukla (2002), Patil et al. (2006), Sindhu and Sharma (2007), Santosh and Shrihari (2008), Ramakrishanaiah et al. (2009) and Samantray et al. (2009). In the present study an attempt is made to establish the baseline water quality of the Chenab river and its tributaries based on WQI.

Water, a natural resource which has been used for different purposes, namely for drinking, domestic, irrigation and industrial, mainly depends on its intrinsic quality hence it is of prime importance to have prior information on quality and quality of water resources available in the region, while planning developmental projects. Water quality index (WQI) is regarded as one of the most effective way to communicate water quality (Kannan 1991; Sinha and Shrivastava 1994; Pradhan et al. 2001). The WQI, which was developed in the nearly 1970s, can be used to monitor water quality changes in a particular water supply over time, or it can be used to compare a water supply's quality with other water supplies in the region or from around the world. The present study was aimed to assess rapid and accurate calculation of WQI of river 
Chenab and its tributaries in Jammu and Kashmir state of India.

NSF WQI is an excellent management and general administrative tool in communicating water quality information. This index has been widely field tested and applied to data from a number of different geographical areas all over the world in order to calculate WQI of various water bodies critical pollution parameters were considered.

The mathematical expression for NSF WQI is given by

$\mathrm{NSF}$ WQI $=\sum_{i=1}^{p} W_{i} I_{i}$

where $I_{i}$ is the sub-index for $i$ th water quality parameter, $W_{i}$ is the weight (in terms of importance) associated with $i$ th water quality parameter, $p$ is the number of water quality parameters.

\section{Experimental}

The Chenab river is formed by the confluence of Chandra and Bhaga river at Tandi located in the upper Himalayas in the Lahul and Spiti district of Himachal Pradesh (Figs. 1, 2). The Chenab valley is structural trough formed by great Himalayan and Pir Panjal ranges. The river flows through hilly terrain having unstable mountain slopes and weak rock strata. Two tributaries, namely Anji khad and Pai khad meet the Chenab river at the downstream. The water samples were collected from the Chenab river and its tributaries from stretch between Ramban to Riasi. The details of sampling locations are presented in Table 1. The water samples were analyzed for physico-chemical and bacteriological parameters following the standard methods (APHA 2005) and the analytical results are presented in Table 2.

In order to calculate WQI critical pollution parameters were considered. The WQI was calculated using standard $Q$ value of each parameter and weighting factor by using NSF information software and compared with standard water quality rating (Table 3 ) and depicted in Table 4.

\section{Results and discussion}

\section{Water quality}

The water quality analysis of Chenab river showed $\mathrm{pH} 8.2$ at all the four locations between Ramban to Riasi. Alkalinity is observed in the range of $40-64 \mathrm{mg} / \mathrm{L}$. Total dissolved solid ranged between 66 and $84 \mathrm{mg} / \mathrm{L}$, total hardness is in the range of $88-104 \mathrm{mg} / \mathrm{L}$, chloride ranged between 6 and $14 \mathrm{mg} / \mathrm{L}$. Sulphate, nitrate and phosphate content were found in the range of 34-36, 6-8 and $0.16-0.29 \mathrm{mg} / \mathrm{L}$ respectively. Sodium and potassium in the water ranged between $1.8-4.1$ and $1.7-2.2 \mathrm{mg} / \mathrm{L}$, respectively. Turbidity ranged between 27 and 178 NTU. Turbidity is observed to be higher as the river flow is rapid and turbulent due to steep gradient and higher rate of erosion in the catchment area.

The water quality analysis of Anji khad, Pai khad, Jalwa khad and spring water source showed total dissolved solid ranged from 180 to $227 \mathrm{mg} / \mathrm{L}$. Alkalinity is observed in the range of $88-196 \mathrm{mg} / \mathrm{L}$, total hardness is in the range of 180-272 mg/L, chloride ranged between 6 and $8 \mathrm{mg} / \mathrm{L}$.

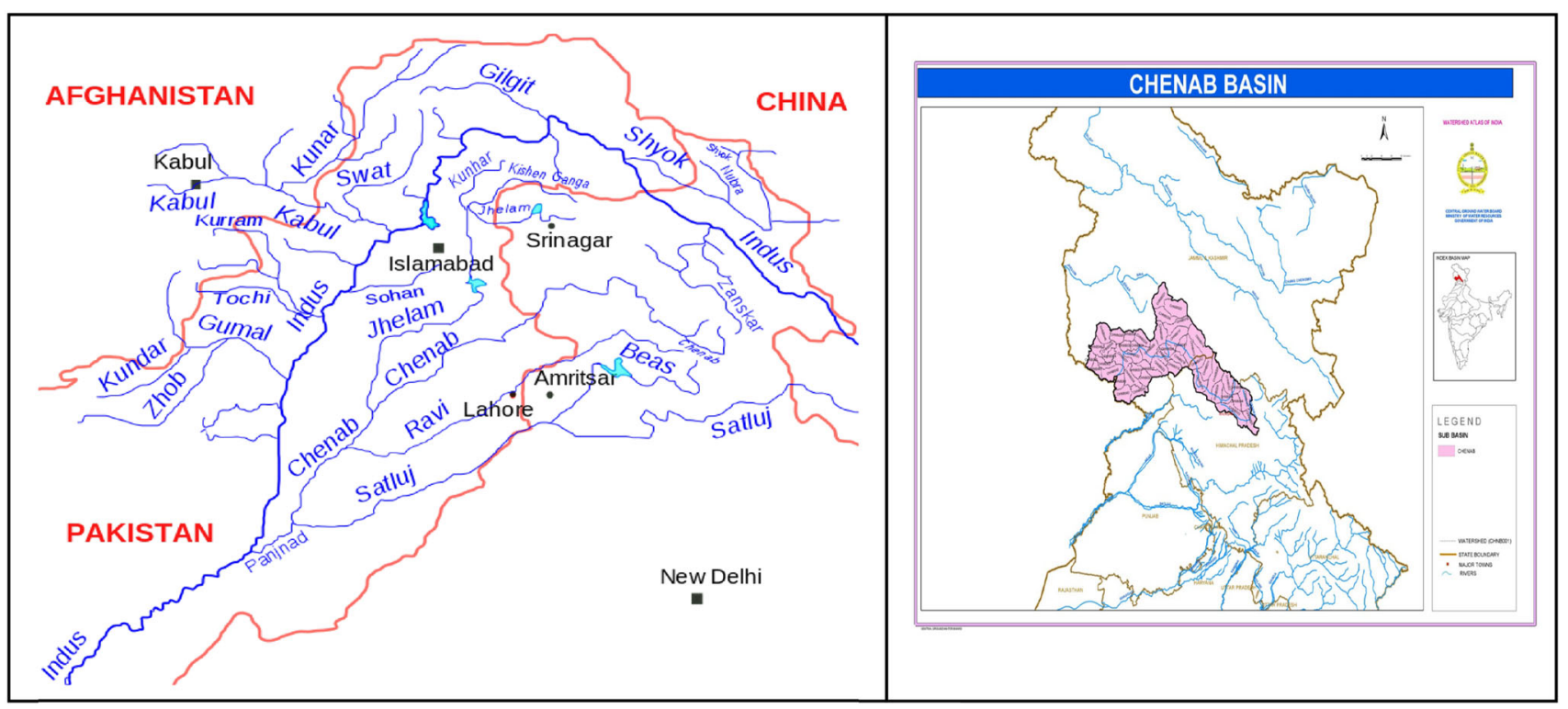

Fig. 1 Study area 


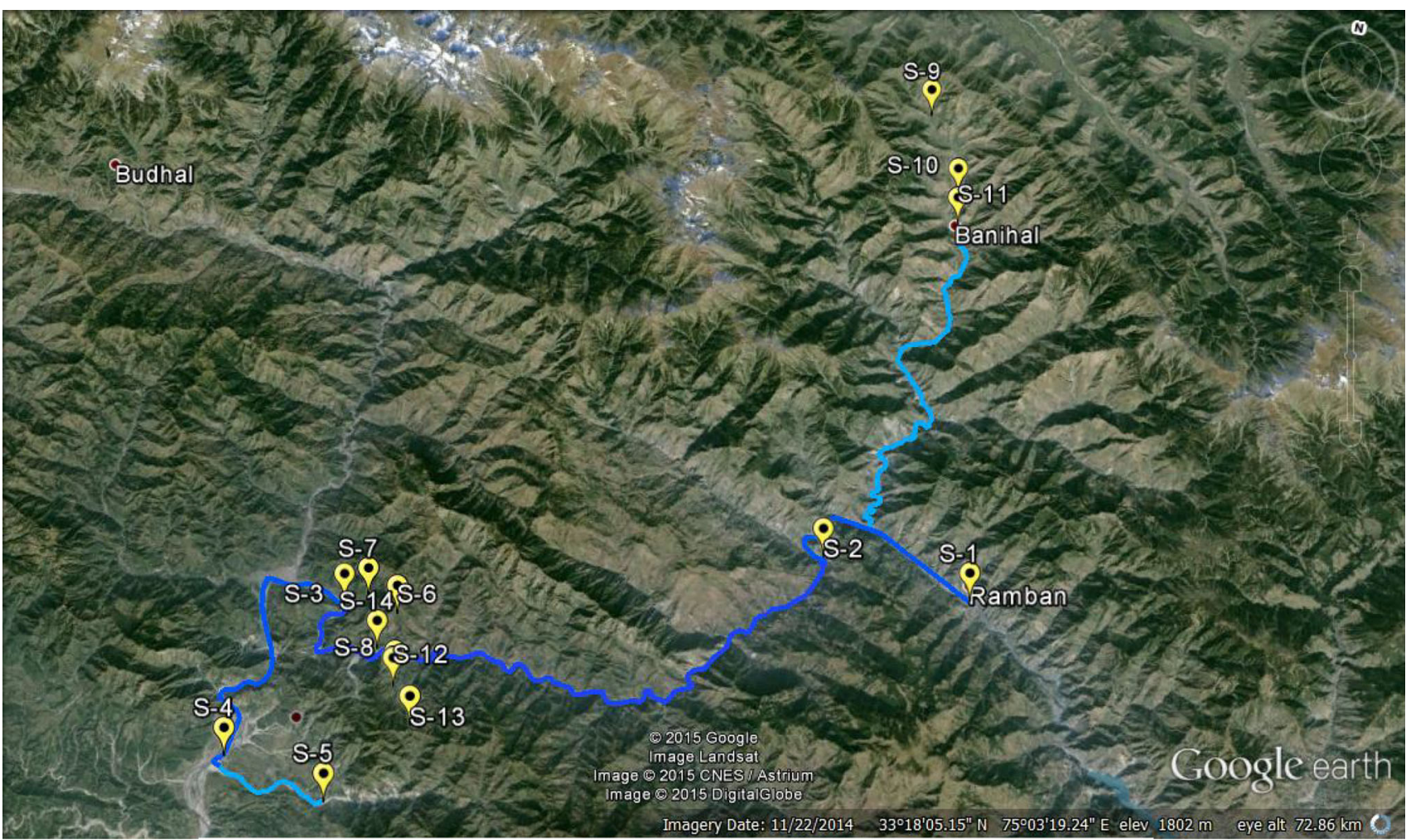

Fig. 2 Google image of study area with sampling locations

Table 1 Water sampling locations of Chenab river and tributaries

\begin{tabular}{|c|c|c|c|c|c|}
\hline S. no. & Sample code & Sampling locations & Longitude (E) & Latitude $(\mathrm{N})$ & Altitude (m) \\
\hline 1 & $\mathrm{~S} 1$ & Chenab river near Ramban town & $75^{\circ} 14^{\prime} 28^{\prime \prime}$ & $33^{\circ} 14^{\prime} 11^{\prime \prime}$ & 700 \\
\hline 2 & $\mathrm{~S} 2$ & Chenab river near Dhamkund village & $75^{\circ} 08^{\prime} 42^{\prime \prime}$ & $33^{\circ} 14^{\prime} 40^{\prime \prime}$ & 633 \\
\hline 3 & S3 & Chenab river from Kanthan bridge & $74^{\circ} 51^{\prime} 10^{\prime \prime}$ & $33^{\circ} 10^{\prime} 25^{\prime \prime}$ & 461 \\
\hline 4 & S4 & Chenab river, $4.5 \mathrm{~km}$ from Reasi & $74^{\circ} 48^{\prime} 14^{\prime \prime}$ & $33^{\circ} 05^{\prime} 06^{\prime \prime}$ & 396 \\
\hline 5 & S5 & Anji khad on Reasi-Katra road, about $1.5 \mathrm{~km}$ from Reasi on Katra road & $75^{\circ} 36^{\prime} 30^{\prime \prime}$ & $33^{\circ} 10^{\prime} 21^{\prime \prime}$ & 444 \\
\hline 6 & S6 & Pai khad, on Reasi-Katra road, near Nandevi Mata Village & $74^{\circ} 53^{\prime} 22^{\prime \prime}$ & $33^{\circ} 10^{\prime} 22^{\prime \prime}$ & 596 \\
\hline 7 & S7 & Jalwa khad, Surandi village, about $8 \mathrm{~km}$ from Kanthal to Kauri road & $74^{\circ} 62^{\prime} 04^{\prime \prime}$ & $33^{\circ} 10^{\prime} 44^{\prime \prime}$ & 656 \\
\hline 8 & S8 & Spring water near $\mathrm{T}_{5} \mathrm{P}_{2}$ end of tunnel joining to Chenab bridge & $74^{\circ} 53^{\prime} 48^{\prime \prime}$ & $33^{\circ} 08^{\prime} 23^{\prime \prime}$ & 854 \\
\hline 9 & S9 & Bitchleri stream near Naugan village & $75^{\circ} 09^{\prime} 58^{\prime \prime}$ & $33^{\circ} 29^{\prime} 58^{\prime \prime}$ & 1969 \\
\hline 10 & $\mathrm{~S} 10$ & Bichleri stream near Banihal station & $75^{\circ} 11^{\prime} 33^{\prime \prime}$ & $33^{\circ} 27^{\prime} 24^{\prime \prime}$ & 1696 \\
\hline 11 & S11 & Bichleri stream flowing by the side of IRCON guest house, Banihal & $75^{\circ} 11^{\prime} 43^{\prime \prime}$ & $33^{\circ} 26^{\prime} 23^{\prime \prime}$ & 1639 \\
\hline 12 & $\mathrm{~S} 12$ & Bichleri stream near Sherbibi, Banihal & $74^{\circ} 53^{\prime} 48^{\prime \prime}$ & $33^{\circ} 08^{\prime} 10^{\prime \prime}$ & 830 \\
\hline 13 & S13 & Mahumannat stream near Nachlana village & $74^{\circ} 54^{\prime} 49^{\prime \prime}$ & $33^{\circ} 07^{\prime} 09^{\prime \prime}$ & 834 \\
\hline 14 & S14 & Bichleri stream near Nachlana after confluence with Mahumannat stream & $74^{\circ} 52^{\prime} 49^{\prime \prime}$ & $33^{\circ} 09^{\prime} 11^{\prime \prime}$ & 839 \\
\hline
\end{tabular}

Sulphate, nitrate and phosphate content ranged between 18 and 32, 5-7, and 0.1 and $0.17 \mathrm{mg} / \mathrm{L}$ respectively. The total and fecal count ranged between 3 and $32 \mathrm{CFU} / 100 \mathrm{~mL}$ and $\mathrm{ND}$ and $10 \mathrm{CFU} / 100 \mathrm{~mL}$, respectively.

Similarly water quality analysis of Bichleri stream showed $\mathrm{pH}$ value in the range of 8.0-8.3. Total dissolved solid of this stream ranged between 40 and $101 \mathrm{mg} / \mathrm{L}$ and increasing trend in TDS value is observed as it flows further. It is due to mixing of wastewater and anthropogenic activity in the source vicinity by the residents. Similarly turbidity ranged between 7 and 33 NTU. Alkalinity is observed in the range of $52-90 \mathrm{mg} / \mathrm{L}$, total hardness is in the range of $40-76 \mathrm{mg} / \mathrm{L}$, chloride ranged between 6 and $30 \mathrm{mg} / \mathrm{L}$. Sodium and potassium content ranges are 1.5-4.8 


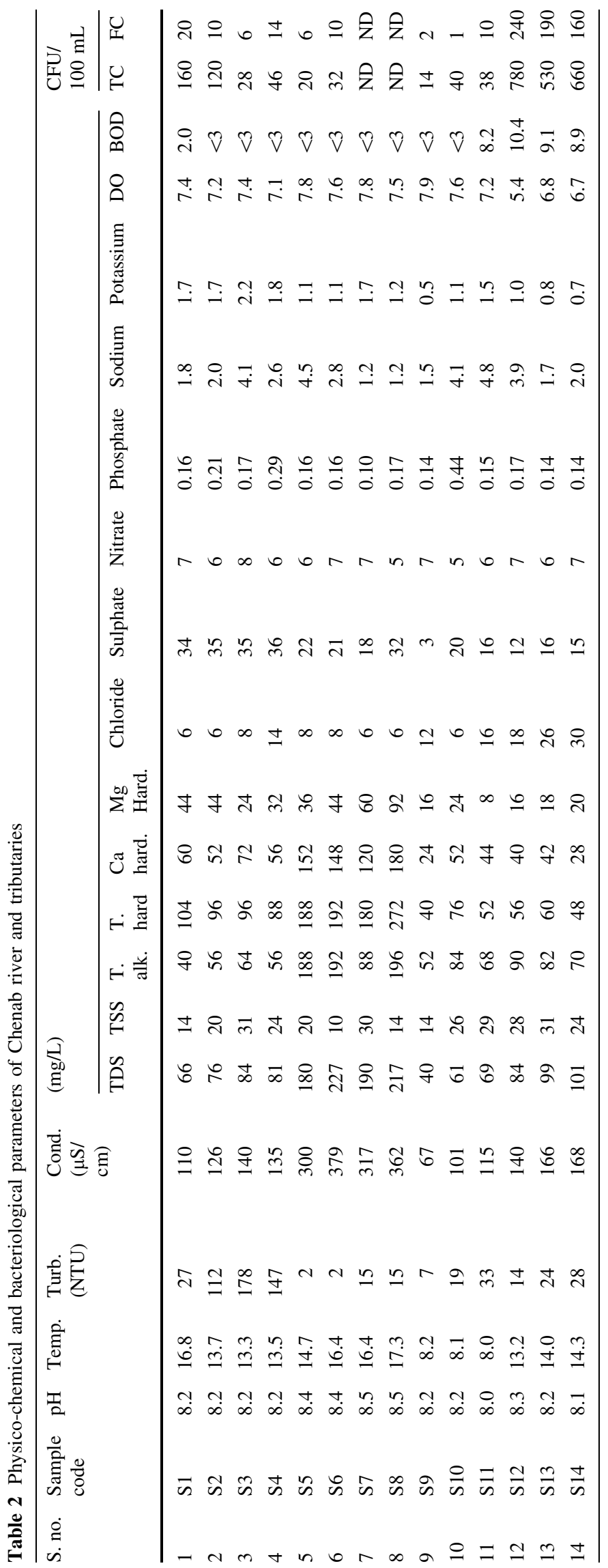


Table 3 Water quality index (WQI) legend

\begin{tabular}{ll}
\hline Range & Quality \\
\hline $91-100$ & Excellent \\
$71-90$ & Good \\
$51-70$ & Medium \\
$26-50$ & Bad \\
$0-25$ & Very bad \\
\hline
\end{tabular}

and $0.5-1.5 \mathrm{mg} / \mathrm{L}$ respectively (Table 2 ). Sulphate, nitrate and phosphate content ranged between 3 and 20, 5 and 7 and 0.14 and $0.44 \mathrm{mg} / \mathrm{L}$, respectively. The TC and FC count showed increasing trend due to mixing of wastewater in the stream generated by the residents of the area. The TC counts were ranged between 14 and $780 \mathrm{CFU} / 100 \mathrm{~mL}$ FC counts were 1-240 CFU/100 mL.

\section{Water quality index (WQI)}

National Sanitation Foundation Water Quality Index (NSF WQI) was developed by selecting parameters rigorously, developing a common scale and assigning weights to the parameters. It has been mentioned in many papers because it's the most comprehensive work. Based on experts opinion rating curves are developed to attribute values for variation in the level of water quality caused by different levels of each of the selected parameters. Computing a water quality index is possible by established rating curves and associated weights. The values of WQI are fed in NSF WQI calculation and obtained the WQI ratings.

A WQI provides a single number (like a grade) that express over all water quality at a certain location and time based on several water quality parameters. Nine parameters i.e. BOD, DO, fecal coliforms, nitrate, $\mathrm{pH}$, temperature change, TDS, total phosphate and turbidity were considered for calculating the WQI for water resources in study area. The water quality data are recorded and transferred to a weighing curve chart, where a numerical value of $\mathrm{Wi}$ is obtained. The observed range of WQI is 70-82 for Chenab river and its tributaries whereas WQI ranged between 61 and 67 for Bicheleri stream (Table 4). The WQI rating for Bichleri stream water is medium because of BOD and presence of coliform bacteria in the water as this water is getting polluted by adding sewage from nearby habitations.

On the basis of the present investigation, it was found that the water of none of the sampling station at Chenab river and tributaries is fit for direct human consumption. The upstream of the river was found clean to slightly pollute and may be used as bathing, swimming, laundry, irrigation, pisciculture and industrial purposes but in downstream sampling stations it was polluted and could be used for domestic purposes after treatment and disinfection.

\section{Conclusion}

The WQI rating (Table 4) showed good water quality, except Bichleri stream, indicating that water of Chenab river and its tributaries, is suitable for drinking after conventional treatment as per CPCB (1995) standards. The Bichleri stream water rating is medium as this stream carries urban wastewater and may not be useful for domestic use. Therefore, it is concluded that the water quality index is an efficient tool to classify the water of the

Table 4 WQI ratings for water quality parameters

\begin{tabular}{|c|c|c|c|c|c|c|c|c|c|c|c|c|}
\hline \multirow[t]{2}{*}{ S. no. } & \multirow[t]{2}{*}{ Sample code } & \multicolumn{9}{|c|}{ Water quality index (WQI) ratings } & \multirow[t]{2}{*}{ Overall WQI } & \multirow[t]{2}{*}{ Water quality grading } \\
\hline & & ${ }_{\mathrm{P}} \mathrm{H}$ & BOD & Temp. change & T. phosphate & Nitrate & Turb. & TS & DO & FC & & \\
\hline 1 & $\mathrm{~S} 1$ & 77 & 80 & 93 & 94 & 58 & 55 & 85 & 70 & 63 & 75 & Good \\
\hline 2 & $\mathrm{~S} 2$ & 77 & 100 & 93 & 91 & 60 & 5 & 84 & 66 & 72 & 73 & Good \\
\hline 3 & S3 & 77 & 100 & 93 & 93 & 56 & 5 & 85 & 68 & 78 & 74 & Good \\
\hline 4 & $\mathrm{~S} 4$ & 77 & 100 & 93 & 82 & 60 & 5 & 83 & 66 & 67 & 71 & Good \\
\hline 5 & S5 & 70 & 100 & 93 & 94 & 60 & 93 & 73 & 77 & 78 & 82 & Good \\
\hline 6 & S6 & 70 & 100 & 93 & 94 & 58 & 93 & 68 & 73 & 72 & 79 & Good \\
\hline 7 & S7 & 66 & 100 & 93 & 96 & 58 & 67 & 70 & 72 & 91 & 80 & Good \\
\hline 8 & S8 & 66 & 100 & 93 & 93 & 65 & 67 & 68 & 74 & 99 & 81 & Good \\
\hline 9 & S9 & 77 & 100 & 92 & 94 & 58 & 82 & 87 & 67 & 91 & 82 & Good \\
\hline 10 & $\mathrm{~S} 10$ & 77 & 100 & 92 & 67 & 65 & 62 & 85 & 60 & 99 & 78 & Good \\
\hline 11 & $\mathrm{~S} 11$ & 84 & 42 & 91 & 94 & 60 & 51 & 84 & 58 & 72 & 70 & Good \\
\hline 12 & $\mathrm{~S} 12$ & 73 & 34 & 92 & 93 & 58 & 69 & 82 & 46 & 36 & 61 & Medium \\
\hline 13 & $\mathrm{~S} 13$ & 77 & 38 & 92 & 94 & 60 & 58 & 81 & 66 & 38 & 65 & Medium \\
\hline 14 & S14 & 80 & 38 & 92 & 94 & 58 & 55 & 81 & 68 & 40 & 67 & Medium \\
\hline
\end{tabular}


river for their various advantageous uses and give an rapid and precise idea about the pollution load in the river that may be worthwhile for policy makers.

\section{References}

APHA, AWWA and WEF (2005) Standard methods for the examination of water and waste water, 21st edn. American Public Health Association, New York

Bhatt SD, Pathak JK (1992) Himalayan Environment: Water quality if drainage basins. Almora, Shri Almora Book Depot, p 318

CPCB (1995) Central pollution control board, classification of inland surface waters (CPCB standards). Water Qual Parivesh 1(4):6

Cude C (2001) Oregon water quality index: a tool for evaluating water quality management effectiveness. J Am Water Resour Assoc 37:125137

Horton RR (1965) An index number system for rating water quality. J Water Pollut Control Fed. 1965(37):300-306

Kannan K (1991) Fundamentals of environmental pollution. S. Chand \& Company Ltd., New Delhi

Kumar A, Shukla M (2002) Water quality index (WQI) of river Sai at Raibareilly city UP. J Ecophysiol Occup Health 2:163-172

Neary B (Ontario Ministry of the Environment), Wright R (Wright Consulting) (2001) Canadian water quality guidelines for the protection of aquatic life. CCME water quality index 1.0 user's manual
Pandey M, Sundaram SM (2002) Trend of water quality of river Ganga at Varanasi using WQI approach. Int J Ecol Environ Sci 28:139142

Patil NJ, Patil GB, Lokande PB, Mujawar HA (2006) Study of physico-chemical parameters of surface waters from Kudalika river near Roha, MIDC, Raigad. IJEP 26(2):167-174

Pradhan SK, Patnaik D, SP SP (2001) Groundwater quality index for groundwater around a phosphatic fertilizers plant. Indian $\mathbf{J}$ Environ Protect 21(4):355-358

Ramakrishanaiah CR, Sadashivaiah C, Ranganna G (2009) Assessment of water quality index for the groundwater in Tumkur Taluk, Karnataka State, India. E J Chem 6(2):523-530

Samantray P, Mishra BK, Panda CR, Rout SP (2009) Assessment of water quality index in Mahanadi and Atharabanki rivers and Taldanda canal in Pradip area, India. J Hum Ecol 26(3):153-161

Santosh MA, Shrihari S (2008) Evaluation of water quality index for drinking purposes for river Natravathi, Mangalore, South India. Environ Monit Assess 143:279-290

Sindhu SK, Sharma A (2007) Study on some physico-chemical characteristics of ground water of district Rampur-a statistical approach. E J Chem 4(2):162-165

Sinha DK, Shrivastava AK (1994) Water quality index for river Sai at Rae Bareli for thepre monsoon period and after the onset of monsoon. Indian J Environ Prot 14(5):340-345

Tiwari TN, Mishra M (1985) A preliminary assignment of water quality index to major Indian rivers. IJEP 5(4):276-279 